\title{
Examining the Condition of Controlling and Inspecting State Vessels (in Terms of Technical and Security Factors) Traveling to Bushehr Ports and Providing Suitable Solutions
}

\author{
Danial Hayati Zadeh*, Behrooz Amraie, Gholamreza Delbar \\ Islamic Azad University, Kharg, Iran \\ Email: "hayati.daniyal@gmail.com \\ Received 25 January 2016; accepted 12 April 2016; published 15 April 2016 \\ Copyright @ 2016 by authors and Scientific Research Publishing Inc. \\ This work is licensed under the Creative Commons Attribution International License (CC BY). \\ http://creativecommons.org/licenses/by/4.0/ \\ (c) (i) Open Access
}

\begin{abstract}
The aim of the study is to examine the technical and security conditions of state vessels traveling to Bushehr ports. This research is filled out through a 22 -item questionnaire by $\mathbf{4 0}$ security and controlling officers of Bushehr vessels. The results of Kolmogrov-Smirinov test suggest that the data are normal and $\mathrm{T}$-test has been used for questionnaire analysis. The findings indicate that failure in technical and security certificates, failure of qualification certificate, failure of machinery and electrical appliances, structural safety defects, failure of telecommunication equipment, failure of security in under 500 tons motor boats and traditional and metal vessels [1]. As well, above 500 tons vessels traveling to Bushehr waters (state vessels) have suitable conditions.
\end{abstract}

\section{Keywords}

Technical and Security Condition, State Vessels, Ports of Bushehr

\section{Introduction}

Control and inspection unit of vessels is responsible of inspecting internal and external vessels in its country's ports in order to adapt vessels with international obligations adopted by instructions and regulations (IMO,

${ }^{*}$ Corresponding author.

How to cite this paper: Zadeh, D.H., Amraie, B. and Delbar, G. (2016) Examining the Condition of Controlling and Inspecting State Vessels (in Terms of Technical and Security Factors) Traveling to Bushehr Ports and Providing Suitable Solutions. Open Journal of Marine Science, 6, 247-257. http://dx.doi.org/10.4236/ojms.2016.62020 
2013). One reason in forming vessels' control and inspection unit is that some state vessels don't observe global standards which consequently result in endangering the lives of seafarers and the environment [2]. Examining the control and inspection condition of some international ports, DNV company showed that most defects identified by vessels' control and inspection officers are located in fire equipment (19\%), ISM regulations (15\%), rescue equipment (13\%) and vessels' machinery (13\%), respectively (DNV, 2012). The information of vessels' control and inspection officers are suitable for traders and shipping lines because they can identify weak-security vessels and reject to make a contract with them (IMO, 2012). International Maritime Organization (IMO) gives right to their all member countries to inspect technical and security test to all vessels entering their ports in order to ensure maritime safety and to protect maritime environment. The countries have merchant marine inspecting their vessels to ensure that they follow the international conventions, avoid repeated inspections and keep their stand and condition in their shipping industry. Controlling and inspecting vessels are one of the effective ways for identifying non-standard vessels (Ports \& Maritime Organization, 2006). Regarding to increased maritime accidents in Bushehr ports as one of main oil exporting ports and the need of Qatar for building materials to implementing its sport projects, it is necessary that the accidents of this port are to be decreased. One of the methods to do so is increasing the condition of vessels' control and inspection [1].

\section{Research's Background}

Chaldavi (2012) examined the defects and solutions of increasing the security of non-convention vessels traveling to Imam Khomeini port. Training, monitoring, sovereignty and supporting in decreasing reported defects by control and inspection unit have higher importance, and to decreasing the accidents originated from structural defects, supporting, monitoring and training, and to decreasing the human accidents, training, sovereignty and monitoring have higher importance, respectively. Hashemi (2013) questioned some accidents in Iran maritime and state vessels in recent years such as accident of Iranian ship off the Chinese coasts and Kosha 1 and the quality of control and inspection centers, hence it is necessary to reinforcing and enhancing control and inspection centers. Based on his research, control and inspection officers of vessels are not consistent with standard national and international obligations and regulations such as apprenticeship, specialized courses and work independence [3].

Liu (2013) said that his goal about writing the article titled "Examining the obligations of vessels' control and inspection in Southern China waters” is enhancing vessels' control and inspection system in line with enhancing maritime environment of the region. The researcher defined three stages for this purpose: The first stage: definition of international obligations related to vessels' control and inspection; the second stage: the experiences of China's ports about preventing polluted vessels in China waters; the third stage: The experiences of European Union in control and inspecting of vessels.

Kujala \& Hannien (2014) designed a relation and model based on the number and kind of defects and traffic amount of a region. The imported information of the model includes vessel's age, kind, vessel's flag, accident and its location reported by VTS.

Fan et al. (2014) stated that flag selection and vessels' inspection center are the two important factor that are selected based on maritime policy. Estimation of foreign effective factors on flag selection and the amount of inspection of vessels' control center are effective in determining suitable policy for improving maritime security [4].

Cariou \& Wolff (2015) stated that the vessels that are not consistent with international regulations are the aim of vessels' control and inspection centers. Although inspecting of vessels is costly, some inspections cannot show some defects. Therefore, the researchers of the research trying to find a pattern for identifying defects and kind of vessels [5].

\section{Research Methodology}

\subsection{The Research's Hypothesis}

Regarding to increased accidents in Bushehr ports, the following hypothesis is made:

- There is a significant relation between suitable implementation and correspondent with international standards of vessels' control and inspection in Bushehr ports, and improving and enhancing state vessels' technical and security factors [6]. 


\subsection{Operational Terms}

- Vessels' control and inspection officer: An expert and qualified person who perform technical and security inspection licensed by Ports \& Maritime Organization and it is exclusively responsible about the organization (Ports and Maritime Organization, 2006).

- Vessels' control and inspection with Iran's flag: vessels' control and inspection with Iran's flag in internal ports or other locations of the world's water by the organization's inspectors to ensuring about corresponding the condition of a vessel with related national and international obligations [7].

\subsection{The Research's Statistical Population and Sample}

In this research, the security experts of Bushehr ports, the control and inspection experts and officers of Bushehr ports make the statistical population of the research (50 people). Regarding to the statistical population of the research (50 people), it is considered as the research's sample.

\subsection{Validity and Reliability of the Questionnaire}

Cronbach's Alpha test is used to determine the reliability of the research. The result of this test is described in Tables 1-4.

In this research, 50 questionnaires was delivered to the research's sample that 40 cases were returned to the researcher. Therefore, data analysis was done based on this 40 questionnaires [8].

\subsection{Data analysis Method}

The inferential method is used in this research because statistical indices are analyzed in it and its significant statistical difference is cleared. Therefore, it is determined that the research's findings are valid, not accidental (Khaki, 2004). The inferential statistical tests are dependent on normality/abnormality of data. Regarding that the normality/abnormality of data are discussed in chapter 4, the normality of data is determined through T-test, and abnormality of data through Chi-square test. SPSS $^{1}$ (version 21) software is used to analyze collected data. For all hypotheses of the research significant level is 0.05 . Therefore, the confidence level of all hypotheses results is $95 \%$ [9].

\section{Results}

\subsection{Descriptive Statistics}

Please see Tables 1-4.

Table 1. The results of Cronbach's Alpha test of vessels' control and inspection factors in Bushehr.

\begin{tabular}{cc} 
Cronbach's alpha & Number \\
\hline 0.79 & 40 \\
\hline
\end{tabular}

Table 2. Work distribution of the respondents.

\begin{tabular}{ccc}
\hline Security unit officer & Vessels' control and inspection expert & Watercraft's control and inspection expert \\
\hline 9 & 23 & 8 \\
\hline
\end{tabular}

Table 3. Work experience of the respondents.

\begin{tabular}{ccc} 
Under $\mathbf{5}$ years & Among $\mathbf{5}$ to $\mathbf{1 0}$ years & More than 10 years \\
\hline 17 & 15 & 8 \\
\hline
\end{tabular}

Table 4. Education level of the respondents.

\begin{tabular}{cccc} 
Under graduated & Bachelor & Master & PhD \\
\hline 7 & 15 & 1 & 7 \\
\hline
\end{tabular}

\footnotetext{
${ }^{1}$ Statistical package for the social sceinces.
} 


\subsection{Inferential Statistics}

Firstly, in this chapter, the results of Kolmogrov-Smirinov are stated to determine whether questionnaire data are normal/abnormal (Table 5).

Regarding to the results of the test, it was determined that the test's amount is between 2 and -2 and the amount of significant level is less than 0.05; therefore data are normal and the researcher must use parametric tests. Since the related data to the questionnaire is normal, the parametric tests ( $\mathrm{T}$ test) are used in inferential tests [10].

\subsection{Questionnaires' Analysis}

\subsubsection{The Defect of Watercraft's Technical and Security Licenses in under 500 Tons Motor Boats and Traditional Watercrafts}

$\mathbf{H}_{\mathbf{0}}$ : The defect of watercraft's technical and security licenses in under 500 tons motor boats and traditional watercrafts is not significant.

$\mathbf{H}_{\mathbf{1}}$ : The defect of watercraft's technical and security licenses in under 500 tons motor boats and traditional watercrafts is significant.

The hypothesis test: As Table 6 shows, the significant level is less than $0.05(0.001)$, so $\mathrm{H}_{0}$ is rejected and

Table 5. The results of Kolmogrov-Smirinov test.

\begin{tabular}{|c|c|c|c|}
\hline Question & Freedom degree & Kolmogrov-Smirinov & Significant level \\
\hline 1 & 39 & 0.845 & 0.000 \\
\hline 2 & 39 & 0.712 & 0.000 \\
\hline 3 & 39 & 0.679 & 0.001 \\
\hline 4 & 39 & 0.605 & 0.000 \\
\hline 5 & 39 & -0.419 & 0.000 \\
\hline 6 & 39 & 0.455 & 0.000 \\
\hline 7 & 39 & 0.773 & 0.000 \\
\hline 8 & 39 & 0.661 & 0.000 \\
\hline 9 & 39 & -0.690 & 0.000 \\
\hline 10 & 39 & 0.550 & 0.000 \\
\hline 11 & 39 & 0.711 & 0.000 \\
\hline 12 & 39 & 0.846 & 0.000 \\
\hline 13 & 39 & 0.846 & 0.000 \\
\hline 14 & 39 & 0.612 & 0.000 \\
\hline 15 & 39 & 0.952 & 0.000 \\
\hline 16 & 39 & 0.514 & 0.002 \\
\hline 17 & 39 & 0.711 & 0.000 \\
\hline 18 & 39 & 0.811 & 0.000 \\
\hline 19 & 39 & 0.943 & 0.032 \\
\hline 20 & 39 & -0.363 & 0.000 \\
\hline 21 & 39 & 0.586 & 0.000 \\
\hline 22 & 39 & 0.139 & 0.000 \\
\hline
\end{tabular}

Table 6. The results of T-test about the defect of watercrafts technical and security licenses in under 500 tons motor boats and traditional watercrafts.

\begin{tabular}{|ccccccc}
\hline \multicolumn{2}{|c}{ 95\% significant level } & Mean difference & Significant level & Freedom degree & t-amount \\
\hline High degree & Low degree & & & & 39 & 3.65 \\
\hline 3.78 & 3.58 & 3.68 & 0.001 & 39 \\
\hline
\end{tabular}


$\mathrm{H}_{1}$ is confirmed, namely the defect of watercraft's technical and security licenses in under 500 tons motor boats and traditional watercrafts is significant.

\subsubsection{The Defect of Qualification Licenses in under 500 Tons Motor Boats and Traditional Watercrafts}

$\mathbf{H}_{\mathbf{0}}$ : The defect of qualification licenses in under 500 tons motor boats and traditional watercrafts is not significant.

$\mathbf{H}_{1}$ : The defect of qualification licenses in under 500 tons motor boats and traditional watercrafts is significant.

The hypothesis test: As Table 7 shows, the significant level is less than $0.05(0.001)$, so $\mathrm{H}_{0}$ is rejected and $\mathrm{H}_{1}$ is confirmed, namely the defect of qualification licenses in under 500 tons motor boats and traditional watercrafts is significant.

\subsubsection{Failure of Machinery and Electrical Appliances in under 500 Tons Motor Boats and Traditional Watercrafts}

$\mathbf{H}_{\mathbf{0}}$ : The failure of machinery and electrical appliances in under 500 tons motor boats and traditional watercrafts is not significant.

$\mathbf{H}_{1}$ : The failure of machinery and electrical appliances in under 500 tons motor boats and traditional watercrafts is significant.

The hypothesis test: As Table 8 shows, the significant level is less than $0.05(0.00)$, so $\mathrm{H}_{0}$ is rejected and $\mathrm{H}_{1}$ is confirmed, namely the failure of machinery and electrical appliances in under 500 tons motor boats and traditional watercrafts is significant.

\subsubsection{Structural Safety Defects in under 500 Tons Motor Boats and Traditional Watercrafts}

$\mathbf{H}_{\mathbf{0}}$ : The structural safety defects in under 500 tons motor boats and traditional watercrafts is not significant.

$\mathbf{H}_{\mathbf{1}}$ : The structural safety defects in under 500 tons motor boats and traditional watercrafts is significant.

The hypothesis test: As Table 9 shows, the significant level is less than $0.05(0.00)$, so $\mathrm{H}_{0}$ is rejected and $\mathrm{H}_{1}$ is confirmed, namely the structural safety defects in under 500 tons motor boats and traditional watercrafts is significant [11].

4.3.5. The Defect of Load Line in under 500 Tons Motor Boats and Traditional Watercrafts

$\mathbf{H}_{\mathbf{0}}$ : The defect of load line in under 500 tons motor boats and traditional watercrafts is not significant.

$\mathbf{H}_{\mathbf{1}}$ : The defect of load line in under 500 tons motor boats and traditional watercrafts is significant.

Table 7. The results of T-test about the defect of qualification licenses in under 500 tons motor boats and traditional watercrafts.

\begin{tabular}{|ccccccc|}
\hline \multicolumn{2}{|c}{ 95\% significant level } & Mean difference & Significant level & Freedom degree & t-amount \\
\hline High degree & Low degree & & & & & \\
\hline 3.45 & 3.25 & 3.30 & 0.000 & 39 & 3.35 \\
\hline
\end{tabular}

Table 8. The results of T-test about the failure of machinery and electrical appliances in under 500 tons motor boats and traditional watercrafts.

\begin{tabular}{|ccccccc}
\hline \multicolumn{2}{|c}{ 95\% significant level } & Mean difference & Significant level & Freedom degree & t-amount \\
\hline High degree & Low degree & & & & 39 & 3.02 \\
\hline 3.06 & 2.98 & 3.04 & 0.000 & 39 \\
\hline
\end{tabular}

Table 9. The results of T-test about structural safety defects in under 500 tons motor boats and traditional watercrafts.

\begin{tabular}{|cccccc}
\hline \multicolumn{2}{|c}{ 95\% significant level } & Mean difference & Significant level & Freedom degree & t-amount \\
\hline High degree & Low degree & & & 3.000 & 39 \\
\hline 3.48 & 3.28 & 3.36 & 35 \\
\hline
\end{tabular}


The hypothesis test: As Table 10 shows, the significant level is less than $0.05(0.001)$, so $\mathrm{H}_{0}$ is rejected and $\mathrm{H}_{1}$ is confirmed, namely defect of load line in under 500 tons motor boats and traditional watercrafts is significant.

\subsubsection{The Defect of Security Equipment and Cases in under 500 Tons Motor Boats and Traditional Watercrafts}

$\mathbf{H}_{\mathbf{0}}$ : The defect of security equipment and cases in under 500 tons motor boats and traditional watercrafts is not significant.

$\mathbf{H}_{\mathbf{1}}$ : The defect of security equipment and cases in under 500 tons motor boats and traditional watercrafts is significant.

The hypothesis test: As Table 11 shows, the significant level is less than $0.05(0.00)$, so $\mathrm{H}_{0}$ is rejected and $\mathrm{H}_{1}$ is confirmed, namely defect of security equipment and cases in under 500 tons motor boats and traditional watercrafts is significant.

\subsubsection{The Failure of Telecommunication Equipment in under 500 Tons Motor Boats and Traditional Watercrafts}

$\mathbf{H}_{\mathbf{0}}$ : The failure of telecommunication equipment in under 500 tons motor boats and traditional watercrafts is not significant.

$\mathbf{H}_{\mathbf{1}}$ : The failure of telecommunication equipment in under 500 tons motor boats and traditional watercrafts is significant.

The hypothesis test: As Table 12 shows, the significant level is less than $0.05(0.000)$, so $\mathrm{H}_{0}$ is rejected and $\mathrm{H}_{1}$ is confirmed, namely the failure of telecommunication equipment in under 500 tons motor boats and traditional watercrafts is significant [13].

\subsubsection{The Defect of Technical and Security Licenses in under 500 Tons Metal Motor Boats and Watercrafts}

$\mathbf{H}_{\mathbf{0}}$ : The defect of technical and security licenses in under 500 tons metal motor boats and watercrafts is not significant.

$\mathbf{H}_{\mathbf{1}}$ : The defect of technical and security licenses in under 500 tons metal motor boats and watercrafts is significant.

The hypothesis test: As Table 13 shows, the significant level is less than $0.05(0.000)$, so $\mathrm{H}_{0}$ is rejected and $\mathrm{H}_{1}$ is confirmed, namely the defect of technical and security licenses in under 500 tons metal motor boats and watercrafts is significant.

Table 10. The results of T-test about the defect of load line in under 500 tons motor boats and traditional watercrafts.

\begin{tabular}{|c|ccccc}
\hline \multicolumn{2}{|c}{ 95\% significant level } & & Mean difference & Significant level & Freedom degree \\
\hline High degree & Low degree & & Memount \\
\hline 3.56 & 3.40 & 3.43 & 0.001 & 39 \\
\hline
\end{tabular}

Table 11. The results of T-test about defect of security equipment and cases in under 500 tons motor boats and traditional watercrafts [12].

\begin{tabular}{|c|c|c|c|c|c|}
\hline \multicolumn{2}{|c|}{$95 \%$ significant level } & \multirow{2}{*}{ Mean difference } & \multirow{2}{*}{ Significant level } & \multirow{2}{*}{ Freedom degree } & \multirow{2}{*}{ t-amount } \\
\hline High degree & Low degree & & & & \\
\hline 3.86 & 3.60 & 3.73 & 0.000 & 39 & 3.69 \\
\hline
\end{tabular}

Table 12. The results of T-test about the failure of telecommunication equipment in under 500 tons motor boats and traditional watercrafts.

\begin{tabular}{|cccccc}
\hline \multicolumn{2}{|c}{ 95\% significant level } & Mean difference & Significant level & Freedom degree & t-amount \\
\hline High degree & Low degree & & & 0.000 & 39 \\
\hline 3.50 & 3.44 & 3.47 & 3.45 \\
\hline
\end{tabular}




\subsubsection{The Defect of Qualification Licenses in under 500 Tons Metal Motor Boats and Watercrafts}

$\mathbf{H}_{\mathbf{0}}$ : The defect of qualification licenses in under 500 tons metal motor boats and watercrafts is not significant.

$\mathbf{H}_{\mathbf{1}}$ : The defect of qualification licenses in under 500 tons metal motor boats and watercrafts is significant.

The hypothesis test: As Table 14 shows, the significant level is less than $0.05(0.000)$, so $\mathrm{H}_{0}$ is rejected and $\mathrm{H}_{1}$ is confirmed, namely the defect of qualification licenses in under 500 tons metal motor boats and watercrafts is significant.

\subsubsection{The Failure of Machinery and Electrical Appliances in under 500 Tons Metal Motor Boats and Watercrafts}

$\mathbf{H}_{\mathbf{0}}$ : The failure of machinery and electrical appliances in under 500 tons metal motor boats and watercrafts is not significant.

$\mathbf{H}_{1}$ : The failure of machinery and electrical appliances in under 500 tons metal motor boats and watercrafts is significant.

The hypothesis test: As Table 15 shows, the significant level is less than $0.05(0.30)$, so $\mathrm{H}_{0}$ is rejected and $\mathrm{H}_{1}$ is confirmed, namely the failure of machinery and electrical appliances in under 500 tons metal motor boats and watercrafts is significant.

\subsubsection{The Defect of Load Line in under 500 Tons Metal Motor Boat and Watercrafts}

$\mathbf{H}_{\mathbf{0}}$ : The defect of load line in under 500 tons metal motor boats and watercrafts is not significant.

$\mathbf{H}_{1}$ : The defect of load line in under 500 tons metal motor boats and watercrafts is significant.

The hypothesis test: As Table 16 shows, the significant level is less than $0.05(0.00)$, so $\mathrm{H}_{0}$ is rejected and $\mathrm{H}_{1}$ is confirmed, namely the defect of load line in under 500 tons metal motor boats and watercrafts is significant.

\subsubsection{The Defect of Security Appliances and Cases in under 500 Tons Metal Motor Boats and Watercrafts}

$\mathbf{H}_{\mathbf{0}}$ : The defect of security appliances and cases in under 500 tons metal motor boats and watercrafts is not significant.

Table 13. The results of T-test about the defect of technical and security licenses in under 500 tons metal motor boats and watercrafts.

\begin{tabular}{|c|c|c|c|c|c|}
\hline \multicolumn{2}{|c|}{ 95\% significant level } & \multirow{2}{*}{ Mean difference } & \multirow{2}{*}{ Significant level } & \multirow{2}{*}{ Freedom degree } & \multirow{2}{*}{ t-amount } \\
\hline High degree & Low degree & & & & \\
\hline 3.40 & 3.26 & 3.33 & 0.000 & 39 & 3.39 \\
\hline
\end{tabular}

Table 14. The results of T-test about the defect of qualification licenses in under 500 tons metal motor boats and watercrafts.

\begin{tabular}{|ccccccc}
\hline \multicolumn{2}{|c|}{ 95\% significant level } & \multirow{2}{*}{ Mean difference } & Significant level & Freedom degree & t-amount \\
\hline High degree & Low degree & & & & & \\
\hline 3.66 & 3.49 & 3.58 & 0.000 & 39 & 3.57 \\
\hline
\end{tabular}

Table 15. The results of T-test about the failure of machinery and electrical appliances in under 500 tons metal motor boats and watercrafts.

\begin{tabular}{|ccccccc}
\hline \multicolumn{2}{|c}{ 95\% significant level } & Mean difference & Significant level & Freedom degree & t-amount \\
\hline High degree & Low degree & & & & 39 \\
\hline 3.68 & 3.56 & 3.64 & 0.003 & 3.61 \\
\hline
\end{tabular}

Table 16. The results of T-test about the defect of load line in under 500 tons metal motor boats and watercrafts.

\begin{tabular}{|cccccc}
\hline \multicolumn{2}{|c|}{$95 \%$ significant level } & Mean difference & Significant level & Freedom degree & t-amount \\
\hline High degree & Low degree & & & 0.000 & 39 \\
\hline 3.96 & 3.84 & 3.80 & 3.86 \\
\hline
\end{tabular}


$\mathbf{H}_{1}$ : The defect of security appliances and cases in under 500 tons metal motor boats and watercrafts is significant.

The hypothesis test: As Table 17 shows, the significant level is less than $0.05(0.00)$, so $\mathrm{H}_{0}$ is rejected and $\mathrm{H}_{1}$ is confirmed, namely the defect of security appliances and cases in under 500 tons metal motor boats and watercrafts is significant.

4.3.13. The Defect of Oil Pollution and Waste in under 500 Tons Metal Motor Boats and Watercrafts

$\mathbf{H}_{\mathbf{0}}$ : The defect of oil pollution and waste in under 500 tons metal motor boats and watercrafts is not significant.

$\mathbf{H}_{1}$ : The defect of oil pollution and waste in under 500 tons metal motor boats and watercrafts is significant.

The hypothesis test: As Table 18 shows, the significant level is less than $0.05(0.00)$, so $\mathrm{H}_{0}$ is rejected and $\mathrm{H}_{1}$ is confirmed, namely the defect of oil pollution and waste in under 500 tons metal motor boats and watercrafts is significant.

\subsubsection{The Defect of Telecommunication Equipment in under 500 Tons Metal Motor Boats and Watercrafts}

$\mathbf{H}_{\mathbf{0}}$ : The defect of telecommunication equipment in under 500 tons metal motor boats and watercrafts is not significant.

$\mathbf{H}_{1}$ : The defect of telecommunication equipment in under 500 tons metal motor boats and watercrafts is significant.

The hypothesis test: As Table 19 shows, the significant level is less than 0.05 (0.023), so $\mathrm{H}_{0}$ is rejected and $\mathrm{H}_{1}$ is confirmed, namely the defect of telecommunication equipment in under 500 tons metal motor boats and watercrafts is significant.

\subsubsection{The Defect in SOLAS Convention in over 500 Tons Vessels}

$\mathbf{H}_{\mathbf{0}}$ : The defect in SOLAS convention in under 500 tons vessels is not significant.

$\mathbf{H}_{1}$ : The defect in SOLAS convention in under 500 tons vessels is significant.

The hypothesis test: As Table 20 shows, the significant level is less than $0.05(0.066)$, so $\mathrm{H}_{0}$ is confirmed and $\mathrm{H}_{1}$ is rejected, namely the defect in SOLAS convention in over 500 tons is not significant.

Table 17. The results of T-test about the defect of security appliances and cases in under 500 tons metal motor boats and watercrafts.

\begin{tabular}{|ccccccc}
\hline \multicolumn{2}{|c}{ 95\% significant level } & Mean difference & Significant level & Freedom degree & t-amount \\
\hline High degree & Low degree & & & & & \\
\hline 3.92 & 3.63 & 3.76 & 0.000 & 39 & 3.79 \\
\hline
\end{tabular}

Table 18. The results of T-test about the defect of oil pollution and waste in under 500 tons metal motor boats and watercrafts.

\begin{tabular}{|ccccccc|}
\hline \multicolumn{2}{|c}{ 95\% significant level } & Mean difference & Significant level & Freedom degree & t-amount \\
\hline High degree & Low degree & & & & & \\
\hline 3.22 & 2.96 & 3.13 & 0.000 & 39 & 3.12 \\
\hline
\end{tabular}

Table 19. The results of T-test about the defect of telecommunication equipment in under 500 tons metal motor boats and watercrafts.

\begin{tabular}{|ccccccc}
\hline \multicolumn{2}{|c}{ 95\% significant level } & Mean difference & Significant level & Freedom degree & t-amount \\
\hline \multicolumn{2}{|c|}{ High degree } & Low degree & & & & \\
\hline 3.76 & 3.65 & 3.68 & 0.023 & 39 & 3.71 \\
\hline
\end{tabular}

Table 20. The results of T-test about the defect of the defect in SOLAS convention in over 500 tons vessels.

\begin{tabular}{|cccccc}
\hline \multicolumn{2}{|c}{ 95\% significant level } & Mean difference & Significant level & Freedom degree & t-amount \\
\hline \multicolumn{2}{|c|}{ High degree } & Low degree & & & \\
\hline 2.30 & 2.10 & 2.20 & 0.066 & 39 \\
\hline
\end{tabular}




\subsubsection{The Defect in MARPOL Convention in over 500 Tons Vessels}

$\mathbf{H}_{\mathbf{0}}$ : The defect in MARPOL convention in over 500 tons vessels is not significant.

$\mathbf{H}_{\mathbf{1}}$ : The defect in MARPOL convention in over 500 tons vessels is significant.

The hypothesis test: As Table 21 shows, the significant level is less than 0.05 (0.053), so $\mathrm{H}_{0}$ is confirmed and $\mathrm{H}_{1}$ is rejected, namely the defect in MARPOL convention in over 500 tons is not significant.

\subsubsection{The Defect in LOAD LINE-66 Convention in over 500 Tons Vessels}

$\mathbf{H}_{\mathbf{0}}$ : The defect in LOAD LINE-66 convention in over 500 tons vessels is not significant.

$\mathbf{H}_{1}$ : The defect in LOAD LINE-66 convention in over 500 tons vessels is significant.

The hypothesis test: As Table 22 shows, the significant level is less than 0.05 (0.061), so $\mathrm{H}_{0}$ is confirmed and $\mathrm{H}_{1}$ is rejected, namely the defect in LOAD LINE-66 convention in over 500 tons is not significant.

\subsubsection{The Defect in ISM CODE in over 500 Tons Vessels}

$\mathbf{H}_{\mathbf{0}}$ : The defect in ISM CODE convention in over 500 tons vessels is not significant.

$\mathbf{H}_{1}$ : The defect in ISM CODE convention in over 500 tons vessels is significant.

The hypothesis test: As Table 23 shows, the significant level is less than $0.05(0.075)$, so $\mathrm{H}_{0}$ is confirmed and $\mathrm{H}_{1}$ is rejected, namely the defect in ISM CODE convention in over 500 tons is not significant.

\subsubsection{The Defect in ILO Convention in over 500 Tons Vessels}

$\mathbf{H}_{\mathbf{0}}$ : The defect in ILO convention in over 500 tons vessels is not significant.

$\mathbf{H}_{\mathbf{1}}$ : The defect in ILO convention in over 500 tons vessels is significant.

The hypothesis test: As Table 24 shows, the significant level is less than 0.05 (0.063), so $\mathrm{H}_{0}$ is confirmed and $\mathrm{H}_{1}$ is rejected, namely the defect in ILO convention in over 500 tons is not significant.

\subsubsection{The Defect in COLREG Convention in over 500 Tons Vessels}

$\mathbf{H}_{\mathbf{0}}$ : The defect in COLREG convention in over 500 tons vessels is not significant.

$\mathbf{H}_{\mathbf{1}}$ : The defect in COLREG convention in over 500 tons vessels is significant.

The hypothesis test: As Table 25 shows, the significant level is less than 0.05 (0.051), so $\mathrm{H}_{0}$ is confirmed and $\mathrm{H}_{1}$ is rejected, namely the defect in COLREG convention in over 500 tons is not significant.

Table 21. The results of T-test about the defect of the defect in MARPOL convention in over 500 tons vessels.

\begin{tabular}{|ccccccc}
\hline \multicolumn{2}{|c|}{$\mathbf{9 5 \%}$ significant level } & Mean difference & Significant level & Freedom degree & t-amount \\
\hline High degree & Low degree & & & & 39 & 2.24 \\
\hline 3.36 & 2.16 & 2.26 & 0.053 & 39 \\
\hline
\end{tabular}

Table 22. The results of T-test about the defect of the defect in LOAD-LINE-66 convention in over 500 tons vessels.

\begin{tabular}{|ccccccc}
\hline \multicolumn{2}{|c}{ 95\% significant level } & Mean difference & Significant level & Freedom degree & t-amount \\
\hline High degree & Low degree & & & & & \\
\hline 2.21 & 2.03 & 2.12 & 0.061 & 39 & 2.11 \\
\hline
\end{tabular}

Table 23. The results of T-test about the defect of the defect in ISM CODE convention in over 500 tons vessels.

\begin{tabular}{|ccccccc}
\hline \multicolumn{2}{|c}{ 95\% significant level } & Mean difference & Significant level & Freedom degree & t-amount \\
\hline \multicolumn{2}{|c|}{ High degree } & Low degree & & & & \\
\hline 2.20 & 2.05 & 2.12 & 0.075 & 39 & 2.10 \\
\hline
\end{tabular}

Table 24. The results of T-test about the defect of the defect in ILO convention in over 500 tons vessels.

\begin{tabular}{|cccccc}
\hline \multicolumn{2}{|c}{ 95\% significant level } & Mean difference & Significant level & Freedom degree & t-amount \\
\hline High degree & Low degree & & & 0.063 & 39 \\
\hline 2.50 & 2.30 & 2.40 & 2.41 \\
\hline
\end{tabular}


Table 25. The results of T-test about the defect of the defect in COLREG convention in over 500 tons vessels.

\begin{tabular}{|cccccc}
\hline \multicolumn{2}{|c}{ 95\% significant level } & Mean difference & Significant level & Freedom degree & t-amount \\
\hline High degree & Low degree & & & & 39 \\
\hline 2.25 & 2.15 & 2.20 & 0.051 & 2.18 \\
\hline
\end{tabular}

Table 26. The results of T-test about the defect of the defect in STCW convention in over 500 tons vessels.

\begin{tabular}{|ccccccc}
\hline \multicolumn{2}{|c}{ 95\% significant level } & Mean difference & Significant level & Freedom degree & t-amount \\
\hline High degree & Low degree & & & & & \\
\hline 2.34 & 2.22 & 2.28 & 0.052 & 39 & 2.38 \\
\hline
\end{tabular}

Table 27. The results of T-test about the defect of the defect in BCH \& IBC convention in over 500 tons vessels.

\begin{tabular}{|cccccc}
\hline \multicolumn{2}{|c}{ 95\% significant level } & & Mean difference & Significant level & Freedom degree \\
\hline High degree & Low degree & & & t-amount \\
\hline 2.50 & 2.20 & 2.35 & 0.051 & 39 \\
\hline
\end{tabular}

\subsubsection{The Defect in STCW Convention in over 500 Tons Vessels}

$\mathbf{H}_{\mathbf{0}}$ : The defect in STCW convention in over 500 tons vessels is not significant.

$\mathbf{H}_{\mathbf{1}}$ : The defect in STCW convention in over 500 tons vessels is significant.

The hypothesis test: As Table 26 shows, the significant level is less than $0.05(0.052)$, so $\mathrm{H}_{0}$ is confirmed and $\mathrm{H}_{1}$ is rejected, namely the defect in STCW convention in over 500 tons is not significant.

\subsubsection{The Defect in BCH \& IBC Conventions in over 500 Tons Vessels}

$\mathbf{H}_{\mathbf{0}}$ : The defect in BCH \& IBC convention in over 500 tons vessels is not significant.

$\mathbf{H}_{\mathbf{1}}$ : The defect in BCH \& IBC convention in over 500 tons vessels is significant.

The hypothesis test: As Table 27 shows, the significant level is less than $0.05(0.51)$, so $\mathrm{H}_{0}$ is confirmed and $\mathrm{H}_{1}$ is rejected, namely the defect in BCH \& IBC convention in over 500 tons is not significant.

\section{Conclusions and Recommendations}

The hypothesis among suitable implementation and along with international standards of vessels' control and inspection in Bushehr's ports and enhancing state vessels' technical and security features has significant relation. So the following suggestions can be made:

1) Increasing man power in vessels' control and inspection centers.

2) Establishing organizational chart for vessels’ control and inspection unit.

3) Improving the condition of control and inspection equipment and their low quality.

4) Creating a suitable motivational system for vessels' control and inspection officers.

5) Mismatching the number of educational courses.

6) Legal problems of contract staffs.

It is recommended to other researchers:

1) To examine the performance condition of the vessels' control and inspection officers in Bushehr.

2) To examine the effective factors on the performance of the vessels' control and inspection officers in Bushehr.

3) To examine the risks and hazards the vessels' control and inspection officers faced with during inspecting vessels.

4) The given trainings to the vessels’ control and inspection officers of Bushehr should be studied.

\section{References}

[1] Azouaou, H., Maison, J. and Gharreb, L. (2014) Development of Guidelines on Port State Control under the 2004 Bwm Convention, 13-65.

[2] Anderson, D. (2008) The Effect of Port State Control on Substandard Shipping. Maritime Studies, 2002, 20. 
[3] Bezgodov, A. and Esin, D. (2014) Complex Network Modeling for Maritime Search and Rescue Operations. ICCS 2014. 14th International Conference on Computational Science, 42-85.

[4] Cariou, C. and Wolff, P. (2015) Identifying Substandard Vessels through Port State Control Inspections. Marine Policy, 60, 27-39. http://dx.doi.org/10.1016/j.marpol.2015.05.013

[5] UNCTAD (2014) Review of Maritime Transport 2014. www.iomou.org/pscmain.htm

[6] Koester, T. (2008) Human Factors in the Maritime Domain. CRC Press, Boca Raton.

[7] Cariou, P., Mejia, Q.M. and Wolff, F.-C. (2007) An Econometric Analysis of Deficiencies Noted in Port State Control Inspection. Maritime Policy and Management, 17, 367-370. http://dx.doi.org/10.1080/03088830701343047

[8] Rajadurai (2007) Regulation of Shipping: The Vital Role of Port State Control. www.austlii.edu.au/au/journals/ANZMarLawJl

[9] Kulchytsky, A. (2012) Legal Aspects of Port State Control. Master Thesis, Lund University.

[10] DNV (2012) Port State Control (PSC) Support. https://www.dnvgl.com/services/port-state-control-psc-support-1548

[11] Fan, L., Luo, M. and Yin, J. (2014) A Risk Assessment System for Improving Port State Control Inspection. Transport Policy 09/2014, 3.

[12] ILO (2007) Port State Control Guide. http://www.imo.org/en/OurWork/MSAS/Pages/PortStateControl.aspx

[13] INTERCARGO (2000) Port State Control: A Guide for Ships Involved in the Dry Bulk Trades. International Association of Dry Cargo Shipowners Publication, London, 10-19. 